Original Research Paper

\title{
Utilization of Moringa Seed Flour as a coagulant, palm fiber, and activated charcoal in an effort to improve domestic wastewater
}

\author{
Maya Roman $^{1}$, Nur Aini Bunyani ${ }^{{ }^{*}}$, Joritha Naisanu ${ }^{1}$ \\ ${ }^{1}$ Universitas Persatuan Guru 1945 NTT, Indonesia
}

\author{
Article History \\ Received : September $15^{\text {th }}, 2020$ \\ Revised : October $07^{\text {th }}, 2020$ \\ Accepted : November $24^{\text {th }}, 2020$ \\ Published : November $29^{\text {th }}, 2020$ \\ *Corresponding Author: \\ Nur Aini Bunyani, \\ Universitas Persatuan Guru 1945 \\ NTT, Indonesia \\ Email: ainibny@gmail.com
}

\begin{abstract}
One local alternative that is available is the use of natural coagulants from the Moringa oleifera L. seed starch plant. Moringa seeds have antimicrobial properties that can reduce substances that should not be present in clean water so that they can purify water for clean water needs. However, the distinctive aroma of moringa is still felt, so it needs to be filtered using coconut shell charcoal and fibers . Research objectives: to determine the characteristics of domestic wastewater ( $\mathrm{pH}$, TSS, BOD, oil and fat) and after adding Moringa seeds as a coagulant and coconut shell charcoal and fibers as a filter media. This research was conducted in Nunleu VillageKupang City and the NTT Provincial Health Laboratory. The method used is experiment and laboratory analysis. Phase I samples were analyzed in the laboratory to determine the characteristics of the initial water. Phase II of water purification experiments with treatment A: coagulant $150 \mathrm{mg} / 1+10$ $\mathrm{cm}$ thick activated charcoal $+10 \mathrm{~cm}$ palm thickness. Treatment $\mathrm{B}$ : coagulant $150 \mathrm{mg} / 1+$ fiber thickness $10 \mathrm{~cm}+$ activated charcoal thickness $10 \mathrm{~cm}$. The results showed that the treatments ( $\mathrm{A}$ and $\mathrm{B}$ ) could reduce $\mathrm{pH}, \mathrm{BOD}, \mathrm{TSS}$ as well as oil and fat. The $\mathrm{pH}$ parameter has decreased tends to be acidic. TSS increased by $58.8 \%$ in Treatment $(\mathrm{A})$, but in treatment (B) there was a decrease of $15 \%$, the TSS content still exceeds the quality standard for domestic waste set by the 2016 Ministerial Regulation, $30 \mathrm{mg} / \mathrm{L}$. The BOD content decreased by $45.2 \%$ in treatment $\mathrm{A}$ while in treatment B there was a decrease of $58.3 \%$. Furthermore, the oil and fat content was quite low, namely in treatment A there was a decrease of $45.2 \%$ while in treatment B there was a decrease of $58.3 \%$.
\end{abstract}

Keywords: Wastewater; Moringa seeds; Charcoal; Palm fiber;

\section{Pendahuluan}

Keberadaan air di muka bumi ini sangat melimpah, namun terancam oleh pengotoran atau pencemaran sebagai akibat kompleksnya aktifitas manusia. Padahal air adalah unsur yang sangat penting untuk eksistensi makhluk hidup. Hal ini telah mengakibatkan terjadinya pencemaran terhadap sumber daya perairan sehingga kualitas air yang ada menjadi menurun bahkan tidak lagi sesuai dengan peruntukannya. Dewasa ini padatnya daerah perkotaan, dan menambah perindustrian membuat air menjadi tercemar. Dimana sumber pencemaran air terjadi pada daerah indusridan daerah yang padat penduduknya. Walaupun telah ada persyaratan tertentu bagi proes industri untuk tidak mencemari lingkungan, dan melakukan kegiatan analisis dampak lingkungan (AMDAL), namun masih banyak limbah
- limbah pabrik yang mencemari air. Padahal, proses industri tersebut telah dihimbau agar tidak merusak kelestarian lingkungan (Sukmasih, 2020).

Pencemar potensial biasanya berasal dari limbah rumah tangga karena hal ini sering kalitidak dapat terpantau oleh pihak yang berwenang. Air limbah ini harus dikelola dengan baikuntuk mengurangi pencemaran dan selain itu air limbah tersebut bisa digunakan untuk keperluan air bersih. Air bersih penting bagi kehidupanmanusia. Banyak tempat di dunia terjadi kekurangan persediaan air. Untuk dapat memanfaatkan air limbah sebagai air bersih maka perlu diuji kualitas airnya. Untuk menguji kualitas air seperti kekeruhan, berwarna dan berbau dapat langsung dideteksi dengan panca indera. Namun air yang terlihat bersih dan tidak berbau belum tentu aman untuk digunakan untuk kehidupan berbagai organime termasuk manusia, karena itu perlu diuji 
Roman, M., et al. (2020). Jurnal BiologiTropis, 20 (3): 467 - 474 DOI: http://dx.doi.org/10.29303/jbt.v20i3.2061

kualitasnya apakah memenuhi syarat atau tidak. Analisis kualitas air dapat dilakukan di laboratorim yang akan mmenghasilkan data yang lengkap dan bersifat kuantitas. Pengolahan Air dilakukan pada air baku yang pada hakekatnya tidak memenuhi standar kualitas bersih yang berlaku, sehingga unsur-unsur yang tidak memenuhi standar perlu dihilangkan ataupun dikurangi, agar seluruh air memenuhi standar yang berlaku (I Dewa Ketut, et.al. 2020). Proses penjernihan air terdiri dari proses kougulasi/flokulasi (penggumpalan) sedimentasi (pengendapan) dan filtasi (penyaringan). Salah satu alternatif yang tersedia secara lokal adalah penggunaan koagulan alami dari tanaman yang barangkali dapat diperoleh di sekitar kita. Penelitian ini dipusatkan pada potensi koagulan dari tepung biji tanaman Moringa oleifera L. Kandungan senyawa yang terdapat di dalam biji kelor memiliki sifat antimikroba yang dapat mereduksi bahan- bahan yang tidak boleh ada pada air bersih (Okto Berkat Gea et.al, 2019). Biji kelor mampu menjernihkan air untuk dapat diperuntukan untuk keperluan air bersih. Namun aroma kelor yang khas masih terasa sehingga perlu difiltrasi menggunakan arang tempurng kelapa. Kebutuhan akan air bersih saat ini semakin meningkat sedangkan jumlah pencemaran air semakin meningkat. Pengujian air limbah domestik untuk diperuntungkan sebagai air bersih dapat dipelajari. Tujuan penelitian adalah untuk mengetahui karekteristik air limbah domestik dari parameter pH,TSS, BOD, serta minyak dan lemak awal sebelum diberikan perlakuan maupun sesudah diberikan perlakuan, serta presentasi penurunan parameter pH,TSS, BOD, serta minyak.

\section{Bahan dan Metode}

\section{Waktu dan tempat}

Penelitian ini dilakukan di Kuanino Jn. Abu Lobo Kelurahan Nunleu, Kecamatan Kota Raja Kota Kupang dan Laboratorium Kesehatan Propinsi NTT berlangsung dari bulan Juni sampai dengan Desember 2020. Metode yang digunakan dalam penelitian ini adalah eksperimen dan analisa laboratorium, selama 3 bulan mulai dari tanggal 24April - 22 Juli 2020

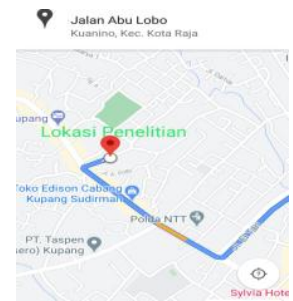

Gambar 1. Lokasi Penelitian

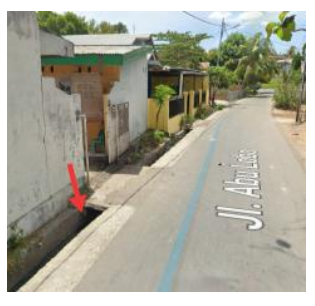

Alat yang digunakan dalam Penelitian ini adalah alat tulis, kamera, kertas label, botol sampel, jerigen, botol aqua dan termos. Bahan yang digunakan
Biji Kelor, arang dan ijuk.
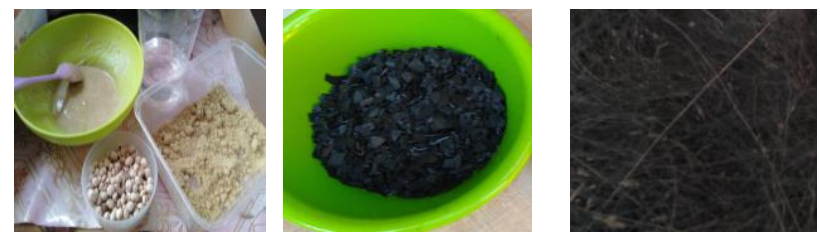

Gambar 2. Tepung biji kelor, arang aktif dan ijuk

Metode yang digunakan dalam penelitian ini adalah metode eksperimen dan analisa laboratorium. Prosedur Kerja: Sebelum proses penjernihan air dilakukan tahapan penelitian dimulai dari persiapan peralatan untuk proses pengolahan air, pengambilan air limbah domestik dilakukan di selokan jalan Abulombo Kuanino Kupang, pembuatan tepung biji kelor untuk koagulan, penyediaan arang tempurung kelapa sebagai media filtrasi, pelaksanaan proses pengolahan air.

\section{Koagulan dan filtrasi:}

(1) Membuat ember pengendapan dan penyaringan (2) Buat lubang $10 \mathrm{~cm}$ dari dasar pada dinding ember untuk pipa penyaring. (3) Pasang kran. (4) Buat lubang pada dasar ember dengan tutup. (5) membuat penyaring yang lebih kecil dari botol mineral ukural 1,5 liter dengan memotong botol tersebut lalu ditempatkan terbalik sehingga bagia atas digunakan sebagai penyaring air limbah domestik.

\section{Pembuatan tepung biji kelor:}

(1) Biji kelor yang tua di pohon dipanen setelah kering. (2) Sayap bijinya yang ringan serta kulit bijinya mudah dipisahkan sehingga meninggalkan biji yang putih. Bila terlalu kering di pohon, polong biji akan pecah dan bijinya dapat melayang "terbang" ke manamana. (3) Biji tak berkulit tersebut kemudian dihancurkan dan ditumbuk sampai halus sehingga dapat dihasilkan bubuk biji Moringa. (4) Jumlah bubuk biji moringa atau kelor yang diperlukan untuk pembersihan air bagi keperluan rumah tangga sangat tergantung pada seberapa jauh kotoran yang terdapat di dalamnya. Untuk menangani air sebanyak $150 \mathrm{mg} / \mathrm{L}$ diperlukan jumlah bubuk biji (Dewa Ketut Ari S., et al., 2020) (5) Tambahkan sedikit air bersih ke dalam bubuk biji sehingga menjadi pasta.

Pembuatan arang:

(1) Menumbuk arang aktif tempurung kelapa lalu diayak

(2) Arang yang digunakan berukuran antar 1-2 $\mathrm{cm}$, dicuci dengan aquades kemudian dikeringkan, lalu siap digunakan.

\section{Pengambilan sampel:}

(1) Menyiapkan jerigen 10 liter sebanyak 6 buah yang sudah dibersihkan sebelumnya. (2) Dilakukan 
Roman, M., et al. (2020). Jurnal BiologiTropis, 20 (3): 467 - 474 DOI: http://dx.doi.org/10.29303/jbt.v20i3.2061

penentuan lokasi dan waktu pengambilan sampel (pukul 10.00 Wita). (3) Pengambilan sampel menggunakan air dilakukan selokan sepanjang Kuanino J1. Abu Lobo Kelurahan Nunleu Kecamatan Kota Raja, Kota Kupang. (4) Sampel dibangi menjadi 2 masing -masing 30 L. dimasukkan ke dalam termos es dibawa ke Laboratorium Kesehatan Propinsi NTT kebutuhan analisa awal dan di bawah ke laboratorium Biologi UPG 45 NTT untuk diberikan perlakuan (5) Pemeriksaan Awal sampel sebelum dilakukan perlakuan, (6) sebelum dan sesuda perlakuan diberi label dan dicantumkan keterangan: Data sampel, Lokasi, pengambilan, Titik sampel, Sumber, Jam dan Tanggal pengambilan sampel, cuaca, dan nama pengirim sampel.

\section{Penerapan Perlakuan:}

Koagulasi:

Untuk proses koagulasi maka Letakkan pasta tepung biji kelor ke dalam botol yang bersih dan tambahkan ke dalamnya s $(200 \mathrm{ml})$ air bersih, lalu kocok selama lima menit hingga tercampur sempurna. Dengan cara tersebut, terjadilah proses aktivitasi senyawa kimia yang terdapat dalam bubuk biji kelor. Saringlah larutan yang telah tercampur dengan kain kasa dan dimasukkan ke dalam air 20 liter air limbah (jeriken) yang telah disiapkan sebelumnya, dan kemudian diaduk secara pelan-pelan selama 30 menit (Saputra, I.D.K.A., et al., 2020).

\section{Filtrasi:}

Air hasil proses kougulasi di filtrasi sesuai dengan perlakuan: (A) arang aktif tempurung kelapa + ijuk dengan ketebalan masing- masing $10 \mathrm{~cm}$. ( B) ijuk + arang aktif tempurung kelapa dengan ketebalan masing- masing $10 \mathrm{~cm}$. dibiarkan dalam filter selama 15 menit, lalu kran dibuka, Sampel air yang sudah difilter dianalisa di Laboratorium Kesehatan Propinsi NTT.

\section{Hasil dan Pembahasan}

\section{Hasil Penelitian Air Limbah Domestik di Laboratoruim}

Sebelum dilakukan pengolahan air limbah, maka dilakukan analisa pendahuluan untuk mengetahui berapa nilai dari setiap parameter uji sehingga pada akhirnya dapat dilakukan perbandingan prosentase penurunan setelah dilakukan pengolahan terhadap limbah.berikutakan ditampilkan hasil analisa laboratorium pada Tabel 1 .

Tabel 1. Hasil Analisa Laboratorium

\begin{tabular}{|c|c|c|c|c|}
\hline $\begin{array}{l}\text { Jenis } \\
\text { pemeri } \\
\text { ksaan }\end{array}$ & $\begin{array}{l}\text { Hasil } \\
\text { Pemeri } \\
\text { ksaan } \\
\text { Awal }\end{array}$ & $\begin{array}{l}\text { Hasil } \\
\text { Pemeriks } \\
\text { aan } \\
\text { setelah } \\
\text { Perlakua } \\
\text { n A }\end{array}$ & $\begin{array}{l}\text { Hasil } \\
\text { Pemeri } \\
\text { ksaan } \\
\text { setelah } \\
\text { Perlaku } \\
\text { an B }\end{array}$ & $\begin{array}{l}\text { Permen } \\
\text { LHK No. } \\
\text { P.68 tahun } \\
2016 \\
\text { Tentang } \\
\text { Baku Mutu } \\
\text { Air } \\
\text { Limbah } \\
\text { Domestik } \\
\text { Tersendiri }\end{array}$ \\
\hline $\mathrm{pH}$ & 8 & 7,5 & 6,5 & $\begin{array}{l}\text { Tidak } \\
\text { disyaratkan }\end{array}$ \\
\hline TSS & $40 \mathrm{mg} / \mathrm{L}$ & $93 \mathrm{mg} / \mathrm{L}$ & $\begin{array}{l}34 \\
\mathrm{mg} / \mathrm{L}\end{array}$ & $30 \mathrm{mg} / \mathrm{L}$ \\
\hline BOD & $\begin{array}{l}88 \\
\mathrm{mg} / \mathrm{L}\end{array}$ & $58 \mathrm{mg} / \mathrm{L}$ & $\begin{array}{l}49 \\
\mathrm{mg} / \mathrm{L}\end{array}$ & $30 \mathrm{mg} / \mathrm{L}$ \\
\hline $\begin{array}{l}\text { Minya } \\
\text { k dan } \\
\text { Lemak }\end{array}$ & $\begin{array}{l}0,680 \\
\mathrm{mg} / \mathrm{L}\end{array}$ & $\begin{array}{l}0,372 \\
\mathrm{mg} / \mathrm{L}\end{array}$ & $\begin{array}{l}0,283 \\
\mathrm{mg} / \mathrm{L}\end{array}$ & $5 \mathrm{mg} / \mathrm{L}$ \\
\hline
\end{tabular}

\section{Kualitas Air Limbah Domestik}

Derajat Keasaman (pH)

Dari hasil pengamatan $\mathrm{pH}$ (Grafik 1) tergolong agak asam sampel awal basa sebelum perlakuan dan pada perlakuan $\mathrm{A}, \mathrm{pH}$ hasil analisa netral akan tetapi pada perlakuan $\mathrm{B}$ pH mengalami penurunan cendrung ke asam. Kondisi $\mathrm{pH}$ yang relatif lebih asam diduga karena adanya penguraian bahan organik, yang menghasilkan karbon dioksida jika bereaksi dengan air dan di dalamnya tidak ada mineral akan menyebabkan kondisi menjadi asam. Hal ini sejalan dengan pernyataan Fardiaz (1992) yang menyatakan pemecahan komponen molekul organik yang mengandung karbon, nitrogen, sulfur dan phospat yang berasal dari karbohidrat, lemak atau protein dalam proses aerobik dan anaerobik akan menghasilkan karbon dioksida yang sifatnya asam.

\section{Parameter $\mathrm{pH}$}

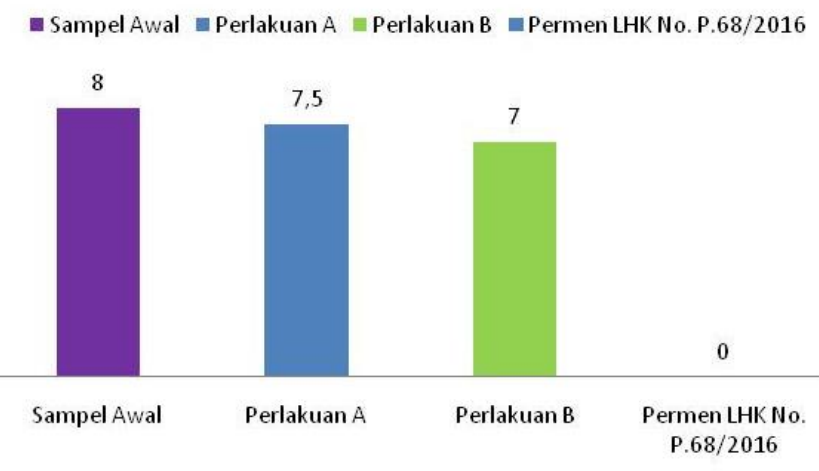

Grafik 1. Nilai $\mathrm{pH}$ setiap sampel 
Hasil penelitian ini bisa disebabkan tingginya penggunaan sabun dan deterjen yang mengakibatkan suasana menjadi basa. Deterjen dan sabun memiliki unsur utama dengan sifat basa, deterjen memiliki natrium $(\mathrm{Na}+)$ pada bahan surfaktan dan bahan pembentuk (builder) memiliki fungsi mengikat ion magnesium dalam jumlah besar sehingga sifat air menjadi alkali (basa) (Fardiaz, 1992), walaupun parameter $\mathrm{pH}$ tidak disyaratkan baku mutu Permen LHK No. P.68/Menlhk/Setjen/Kum.1/8/2016, Tentang Baku Mutu Air Limbah. Hasil pengukuran $\mathrm{pH}$ sesudah penyaringan menunjukkan terjadinya penurunan $\mathrm{pH}$ dari $\mathrm{pH} 8$ menjadi $\mathrm{pH} 7,5$ perlakuan $\mathrm{A}$ dan pada perlakuan $\mathrm{B}$ menjadi cendrung asam $\mathrm{pH}$ 6,5. menurut Pandia (2010) penambahan biji Moringa kedalam air akan memberikan sedikit pegaruh terhadap $\mathrm{pH}$ air atau secara umum tidak terlalu signifikan. Penurunan $\mathrm{pH}$ terjadi karena biokoagulan bersifat asam lemah sehingga mampu menurunkan $\mathrm{pH}$ pada limbah. Asam lemah berasal dari gugus karboksil asam amino melepaskan ion hidrogen $(\mathrm{H}+)$ dalam limbah yang diolah. Berdasarkan analisa tersebut dapat disimpulkan biokoagulan Moringa bersifat asam lemah (Aritonang, et al., 2013).

\section{Padatan Tersuspensi Total (TSS)}

Hasil penelitian ini terlihat bahwa jumlah total padatan tersuspensi yang ada di lokasi penelitian, melebihi baku mutu limbah domestik. Pada penelitian ini nilai TSS yang dihasilkan pada umumnya masih cukup tinggi, seteleh air limbah domestik ini diolah dengan menambahkan tepung biji kelor sebagai koagulan dan arang tempurung kelapa sebagai media filter nilai TSS mengalami kenaikan sebesar $58,8 \%$ pada perlakuan A tetapi pada perlakuan B terjadi penurunan sebesar $15 \%$ masih belum memenuhi baku mutu lingkungan bahkan berada di luar batas ambang yang diperbolehkan Permen LHK No. P.68/Menlhk/Setjen/Kum.1/8/2016, 30mg/l. Untuk lebih jelasnya konsentrasi TSS pada setiap sampel dapat dilihat pada Grafik 2.

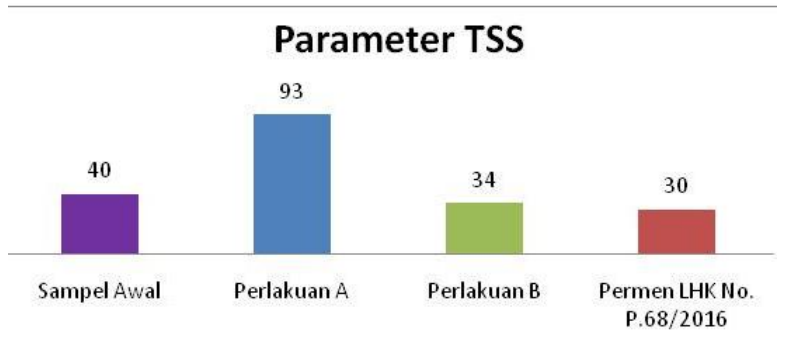

GGrafik 2. Nilai TSS

Penambahan konsentrasi koagulan tidak meningkatkan kemampuan koagulan mengikat padatan tersuspensi yang masih tersisa, namun menggangu kestabilan makroflok, sehingga makroflok pecah. Selain itu koagulan yang tidak mengikat padatan tersuspensi akhirnya akan menambah padatan total tersuspensi hal ini sejalan dengan hasil penelitian (Siregar, 2005), penambahan biokoagulan yang melebihi dosis optimum akan menyebabkan peningkatan kembali nilai TSS di dalam air limbah. Sedangkan penurunan konsentrasi TSS pada limbah domestik juga disebabkan karena flok-flok yang diendapakan sesuai dengan waktu pengendapan optimum biokoagulan. Waktu pengendapan yang optimum akan menghasilkan flok yang mengendap deng an maksimum pada dasar wadah. Analisis uji sidik ragam konsentrasi biji kelor dan lama pengendapan berpengaruh sangat nyata terhadap penurunan total coliform dan TSS. Hasil penelitian menunjukkanbahwa pengamatan yang dilakukan pada parameter total coliform dan TSS, konsentrasi serbuk bijikelor optimum terbaik hingga $150 \mathrm{mg} / \mathrm{L}$ dan lama pengendapan optimum 60 menit mampumenurunkan total bakteri coliform dan TSS. Namun pada penurunan TSS efesien pada lamapengendapan 20 menit (Gea, et.al., 2019) selanjutnya konsentrasi biji kelor yang digunakan dalam penelitian ini yakni 50 $\mathrm{mg} / \mathrm{L}, 100 \mathrm{mg} / \mathrm{L}$ dan $150 \mathrm{mg} / \mathrm{L}$ mampu menurunkan nilai TSS limbah peternakan sapi.Seperti halnya konsentrasi yang digunakan pada penelitian Wibawarto et al., (2017), dengan konsentrasi awal 40 $\mathrm{mg} / \mathrm{L}$ sudah memberikan hasil yang paling baik untuk menurunkan nilai TSS. Hal ini membuktikan bahwa pemberian koagulan biji kelor yang bermuatan positif akan berinteraksi dengan partikel-partikel bermuatan negatif dalam limbah sehingga membentuk flok-flok melalui mekanisme adsorbsi (Sari et al., 2017).Serbuk biji kelor akan mengikat partikel-partikel membentuk flok-flok yang terbentuk pada pengadukan cepat. Pengadukan kedua diperlambat untuk memperbesar flok yangterbentuk pada pengadukan pertama, sehingga flok mikro bergabung menjadi satu denganmassa yang lebih besar sehingga mengendap dan turun ke dasar beaker glass. Tujuanpengadukan adalah untuk mencampurkan larutan biji kelor ke dalam limbah sehingga dapatbereaksi dengan partikelpartikel atau ion-ion yang berada dalam limbah. Pernyataan inidiperkuat oleh hasil penelitian Khasanah (2008) bahwa proses koagulasi dipengaruhi olehberbagai macam faktor, termasuk konsentrasi koagulan. Konsentrasi koagulan danpengadukan yang tepat mampu mengendapkan dan mampu mengurangi partikel koloidpenyebab kekeruhan dalam air limbah secara maksimal. Hal ini menyebabkan TSS dalam airlimbah peternakan sapi menjadi berkurang (Gea, 2019).

\section{Biochemical Oxygen Demand (Kebutuhan Oksigen Biokimiawi)}


Hasil analisis BOD pada penelitian ini terlihat bahwa nilai BOD di hampir semua titik penelitian adalah sangat rendah (Gambar 3) dan berada dalam kondisi yang di bawah ambang batas yang ditentukan oleh Permen LHK No. P.68/Menlhk/Setjen/Kum.1/8/2016, 30mg/l.

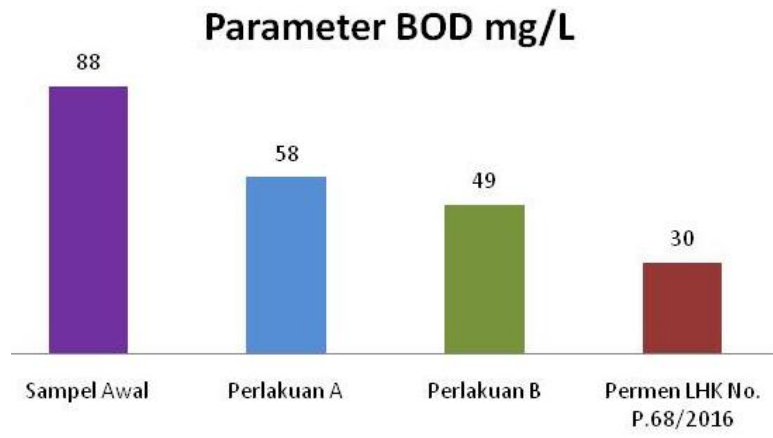

Gambar 3. Grafik nilai BOD

Hasil penelitian menunjukkan terjadi penurunan konsentrasi BOD 34\% pada perlakuan A sedangkan pada perlakuan $\mathrm{B}$ terjadi penurunan sebesar $44 \%$. Pada perlakuan dengan biokoagulan terjadi proses penurunan nilai BOD dikarenakan biokoagulan mengikat koloid zat organik pa da limbah. Koloid-koloid pada limbah akan terikat oleh rant ai polimer biokoagulan dan membentuk mikro flok. Mikroflok akan saling berikatan sehingga membentuk makroflok yang sehingga kemudian akan mengendap secara grafitasi. zat organik yang mengendap terikat rantai polimer, akan disisihkan pada waktu pengendapan sehingga limbah yang diolah akan berkurang kandungan zat organiknya. Hasil penelitian dudukung oleh Aritonang, et al., 2013, dengan biokoagulan Moringa mampu menurunkan kosentrasi BOD sebesar 79,15\%. Menurut hidayat (2006)limbah domestik selain mengandung material organik jug mengandung mikroorganisme.Aktivitas mikroorganisme menguraikan zat organik untuk sebagai makananya menggunakan terlarut pada air limbah. Turunnya zat organik oksigen menyebabkan kandungan oksigen terlarut pada air meningkat sehingga terjadi peningkatan di kualitas air limbah domestik.

Keberadaan bahan organik dalam air limbah, dapat diekspresikan dengan besarnya konsentrasi BOD dalam air limbah. Kandungan bahan organik yang terdapat pada air limbah salah satu rumah di selokan Kuanino Kota Kupang dengan konsentrasi awal untuk BOD sebesar 0,68 mg/L , menurut Rump dan Krist dalam Effiendi, (2003) merupakan air limbah dengan tingkat pencemaran sedang.Tidak begitu besarnya kandungan BOD dalam air limbah tersebut dapat dimengerti, mengingat bahwa limbah domestik tersebut hanya berasal dari kegiatan domestik limbah rumah tangga, dalam pengertian bahwa dari lokasi tersebut tidak terdapat berbagai aktivitas usaha yang potensial menimbulkan polutan bahan organik dalam jumlah yang besar dan atau dengan konsentrasi yang cukup tinggi, seperti : pasar, pusat pertokoan / mall ataupun rumah makan (restaurant). Disamping itu, umumnya yang dibuang ke perairan umum, menurut Veenstra (1995) merupakan limbah yang termasuk kategori gray water, yaitu air limbah berasal dari buangan dapur dan kamar mandi, yang pada umumnya tidak mengandung polutan (terutama bahan organik) dengan konsentrasi yang cukup tinggi. Sesuai dengan Keputusan Permen LHK No. P.68/Menlhk/Setjen/Kum.1/8/2016, 30mg/l. tentang Baku Mutu Air Limbah Domestik, telah mempersyaratkan bahwa kandungan BOD dalam air limbah domestik yang boleh dibuang ke perairan umum adalah $30 \mathrm{mg} / \mathrm{L}$. Berdasarkan penelitian yang dilakukan maka pengolahah dengan menggunakan koagulasi tepung biji kelor dapat memperbaiki nilai BOD yaitu pada sebelum adanya perlakuan BOD $0,680 \mathrm{Mg} / \mathrm{L}$, perlakuan A. BOD $0,720 \mathrm{Mg} / \mathrm{L}$, sedangkan Perlakuan B, BOD 0, 283Mg/L. BOD merupakan sejumlah oksigen yang dibutuhkan oleh bakteri aerobik untuk menguraikan dan menstabilkan bahan organi, melalui proses aerobik biological oxidation. Bila nilai BOD tinggi berarti kebutuhan organisma pengurai akan oxygen meningkat. Apabila kebutuhan oksigen tidak terpenuhi maka organisma pengurai tidak akan menguraikan bahan organik dan ekosistem akan terganggu ( Mahida, 1984). Disamping itu, agar sistem pengolah limbah tersebut dapat terpelihara dengan baik, maka diperlukan sistem pengolah limbah yang mudah dan murah operasionalnya yaitu dengan menggunakan tepung biji kelor sebagai koagulasi dan arang tempurung kelapa sebagai media filtrasi.

\section{Minyak dan Lemak}

Pada penelitian ini terlihat bahwa kandungan minyak dan lemak sampel awal adalah $0,68 \mathrm{ml} / \mathrm{L}$ dan pada saat air mengalami perlakuan dengan proses koagulasi konsentrasi minyak dan lemak masih rendah dan berada di bawah ambang batas yang ditetapkan baku mutu Permen LHK No. P.68/Menlhk/Setjen/Kum.1/8/2016 tentang Baku Mutu Air Limbah Domestik yakni 5 mg/l. Hasil pengamatan terhadap kandungan minyak dan lemak di setiap sampel pada penelitian ini dapat dilihat pada Gambar 4. 


\section{Parameter Minyak dan Lemak} $\mathrm{mg} / \mathrm{L}$

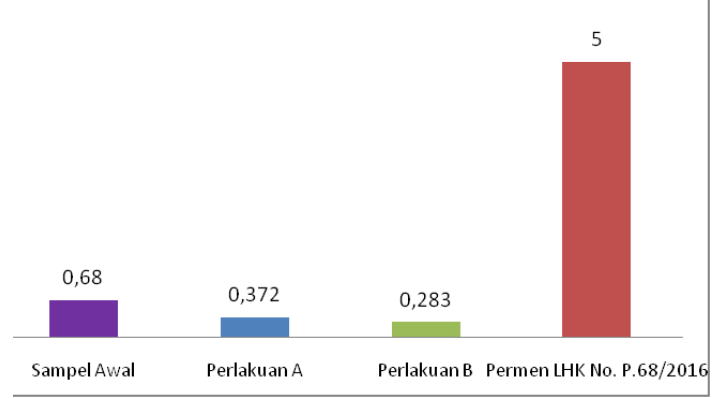

Grafik 4. Nilai minyak dan lemak

Hasil analisa laboratorium kandungan minyak dan lemak cukup rendah yaitu pada perlakuan A terjadi penurunan $45,2 \%$ sedangkan perlakuan B terjadi penurunan $58,3 \%$. Hal ini disebabkan tempat pengambilan sampel kegiatan hanya memasak di Rumah tangga saja ini umumnya tidak menggunakan bahan- bahan yang mengandung minyak dan lemak. Minyak dan lemak pada air limbah diduga berasal dari penggunaan minyak goreng, minyak ikan, daging dan biji-bijian (Sugiharto, 1987), selanjutnya menjelaskan lebih lanjut bahwa adanya minyak dan lemak perlu diwaspadai, karena minyak dan lemak akan melapisi/menutup permukaan air, sehingga aktivitas biologis yang terjadi pada perairan akan terganggu. Selain itu minyak dan lemak ini di dalam perairan juga akan menurunkan estetika perairan, serta akan menghalangi masuknya sinar matahari ke dalam perairan. Konsentrasi minyak dan lemak dapat berkurang disebabkan oleh model anyaman koloid. Hal tesebut dapat dijelaskan dengan polimer biokoagulan saling berikatan dengan koloid. Pada saat polimer mengikat koloid, maka minyak dan lemak akan terperangkap dalam ikatan tersebut dan membentuk flok. Flok-flok yang terbentuk mengendap sehingga konsentrasi minyak dan lemak pada air limbah turun. Hal ini didukung Mezi (2008) yang menyatakan bahwa biokoagulan mampu menurunkan konsentrasi minyak dan lemak pada air limbah melalui pembentukan anyaman koloid.

\section{Kesimpulan}

Hasil penelitian menunjukkan, pemberian tepung biji kelor $150 \mathrm{mg} / \mathrm{L}$ sebagai koagulan dan penyaring menggunakan arang aktif tempurung kelapa $10 \mathrm{~cm}+\mathrm{Ijuk} 10 \mathrm{~cm}$ (A) dapat menurunkan $\mathrm{pH}$, BOD, TSS serta minyak dan Lemak. Parameter $\mathrm{pH}$ mengalami penurunan cendrung ke asam. TSS mengalami kenaikan sebesar $58,8 \%$ pada perlakuan pemberian tepung biji kelor $150 \mathrm{mg} / \mathrm{L}$ sebagai koagulan dan penyaring menggunakan Ijuk10 cm +Arang aktif $10 \mathrm{~cm}$ (B) tetapi pada perlakuan pemberian tepung biji kelor $150 \mathrm{mg} / \mathrm{L}$ sebagai koagulan dan penyaring menggunakan arang aktif tempurung kelapa $10 \mathrm{~cm}+$ Ijuk10 $\mathrm{cm}$ terjadi penurunan sebesar $15 \%$, kandungan dan TSS masih melebihi baku mutu limbah domestik yang ditetapkan Permen LHK No. P.68/Menlhk/Setjen/Kum.1/8/2016, 30mg/l. Kandungan BOD $45,2 \%$ pada perlakuan A sedangkan pada perlakuan B terjadi penurunan sebesar $58,3 \%$. Hasil analisa laboratorium kandungan minyak dan lemak cukup rendah yaitu pada perlakuan A terjadi penurunan $45,2 \%$ sedangkan perlakuan B terjadi penurunan $58,3 \%$

\section{Ucapan Terima Kasih}

Terima kasih kepada Kementerian Pendidikan dan Kebudayaan atas dukungan dana yang diberikan dalam bentuk penelitian dosen pemula da Rektor UPG 45 NTT yang telah mendukung baik moril maupun materil dalam pelaksanaan penelitian ini. Pemerintah Kota Kupang, Lurah Nunleu.

\section{Referensi}

Aritonang, D.O. H., Mumu Sutisna \& Moh. Rangga. (2013). Pengolahan Limbah Domestik dengan menggunakan Biokoagulanb Biji Moringaoleiferalam dan Saringan Pasir Cepat. Jurnal Institut Teknologi Nasional. Teknik Lingkungan Itenas, 1(2), 69-80.

Effendi, H. (2003). Telaah Kualitas Air Bgai Pengelolaan Sumber Daya dan Lingkungan Perairan. Yogyakarta. Kanisius

Fardiaz, S. (1992). Polusi Air dan Udara. Yogyakarta: Kanisius.

Khasanah Uswatun (2008). Efektifitas Biji Kelor (moringa oleiver LAMK) Sebagai Keagulan Fosfat Dalam Limbah rumah Sakit. Skripsi Universitas Islam Negeri Malang. http://etheses.uinmalang.ac.id/4603/1/03530023.pdf

Gea, O. B., I Ketut Suada \& I Made Mardana (2019).Penggunaan Serbuk Biji Kelor untuk Penanganan Limbah Peternakan Sapi Ditinjau dari Total Coliform dan Total Suspended Solid. Indonesia Medicus Veterinus, Mei 2019 8 (3): 303-312.

Hendrawati, Indra Rani Yuliastri, Nurhasni, Eti Rohaeti, Hefni Effendi \& Latifah K Darusman. (2015). The use of Moringa Oleifera Seed 
Powder as Coagulant to Improve the Quality of Wastewater and Ground Water. Published under licence by IOP Publishing Ltd.IOP Conference Series: Earth and Environmental Science, Volume 31, Workshop and International Seminar on Science of Complex Natural Systems9-10 October 2015, Bogor, Indonesiahttps://iopscience.iop.org/article/10. $\underline{1088 / 1755-1315 / 31 / 1 / 012033}$

Hidayat, S. (2006). Pemberdayaan Masyarakat Bantaran Sungai Lematang Dalam Menurunkan Kekeruhan Air Dengan Biji Kelor (Moringa oleifera, Lamk) Sebagai Upaya Pengembangan Proses Penjernihan Air. Malang: Disertasi, Program Pasca Sarjana, Universitas Negeri Malang

Irmayana, I., Hadisantoso, E. P., \& Isnaini, S. (2017). Pemanfaatan Biji Kelor (Moringa oleifera) sebagai koagulan alternatif dalam proses penjernihan limbah cair industri tekstil kulit. Jurnal Istek, 10(2). https://journal.uinsgd.ac.id/index.php/istek/art icle/view/1477

Mahinda N.U. (1984) Pencemaran air dan pemanfaatan limbah industri. C.V. RajawaliJakarta.

https://books.google.co.id/books/about/Pence maran_air_dan_pemanfaatan_limbah_in.html ?id=-wcNPAAACAAJ\&redir_esc $=y$

Mezi, A. A. (2008). Efektivitas Bioflokulan Moringa oleifera Lam. Dalam Memperbaiki Kualitas Fisika Kimia Air Limbah Industri Tekstil. Bandung: Unpublished Skripsi, Program S-1 Jurusan Teknik Lingkungan Institut Teknologi Nasional.

https://core.ac.uk/download/pdf/132123116.p $\underline{\text { df }}$

Nilasari, E., Faizal, M. F. M., \& Suheryanto, S. (2016). Pengolahan Air Limbah Rumah Tangga dengan Menggunakan Proses Gabungan Saringan Bertingkat dan Bioremediasi Eceng Gondok (Eichornia crassipes), (Studi Kasus di perumahan Griya Mitra 2, Palembang). Jurnal Penelitian Sains, 18(1), 8-13. http://ejurnal.mipa.unsri.ac.id/index.php/jps/a rticle/view/34

Pandia, S. d. (2010). Pengaruh Massa dan Ukuran Biji Kelor pada Proses Penjernihan Air. In R. S. Irianty Pengaruh Massa Biji Kelor (Moringa oleifera Lamk) dan Waktu Pengendapan pada Air Gambut. Riau Unpublished Skripsi, Program S- Jurusan Teknik Kimia Fakultas Teknik Universitas Riau

Permen LHK No. P.68/Menlhk/Setjen/Kum.1/8/2016. http://sustainability.ipb.ac.id/wpcontent/uploads/2020/01/Permen-LHK-No68-tahun-2016-tentang-Baku-Mutu-AirLimbah-Domestik.pdf

Priyanto, D. A., \& Nisa, C. F. (2016). Formulasi daun kelor dan ampas daun cincau sebagai tepung komposit pada pembuatan mie instan. Jurnal Teknologi Pertanian, 17(1), 29-30.

Rahardjanto, A. (1998). Efektivitas Bioflokulan Moringa oleifera Lam. Dalam Memperbaiki Sifat Fisika Kimia Air Limbah Industri Tekstil. Bandung: Unpublished Thesis, Program Pasca Sarjana Studi Biologi Institut Teknologi Bandung.

Saputra, I.D.K.A., I Ketut Suanda \& I Made Merdana. (2020). Pemberian Biji Kelor pada Limbah Ayam Tradisional Mampu Menurunkn Jumlah Escherichia coli. Indonesia Medicus Veterinus, Maret 2020, 9 (2): 148-156.

Sari RA, Pinem JA \& Daud S. (2016). Pemanfaatan Biji Kelor (Moringa Oleifera) Sebagai Koagulan Pada Pengolahan Air Payau Menjadi Air Minum Menggunakan Proses Koagulasi Ultrafiltrasi. Jom FT. 3(1): 1-7

Sari RK, Tina L \& Fachlevy AF. (2017). Efektifitas Biji Kelor (Moringa Oleifera) Terhadap Bakteri Escherichia Coli Dalam Upaya Pencegahan Penyakit Diare. Jurnal Ilmiah Kesehatan Masyarakat Unsiyah 2(6): 6-7.

Siregar, SA. (2005). Instalasi Pengolahan Air Limbah. Yogyakarta: Kanisius. prints.ums.ac.id/26104/10/pdf

S. Veenstra (1995), Wastewater Treatment, International Institute for Infrasructural, Hydraulic and Environmental Engineering. The Netherlands. https://www.google.com/search?q=S.+Veenst $\underline{\text { ra },+1995,+ \text { Wastewater+Treatment, }+ \text { Internatio }}$ nal+Institute+for+Infrastructure

Sugiarto, Tri Anto (2003). Pengolahan Air Limbah, Pusat Penelitian KIM-LIPI, http: // www.inovasi.lipi.go.id 
Roman, M., et al. (2020). Jurnal BiologiTropis, 20 (3): 467 - 474 DOI: http://dx.doi.org/10.29303/ibt.v20i3.2061

Wibawarto DK, Syafrudin \& Nugraha WD. (2017). Study Penurunan Turbidity, TSS, COD Menggunakan Biji Kelor (Moringa Oleifera) Sebagai Nanobiokoagulan Dalam, Pengolahan Air Limbah Domestik (Grey Water). Jurnal Teknik Lingkungan. 6(1): 2- 3. https://www.neliti.com/publications/141739/st udy-penurunan-turbidity-tss-codmenggunakan-biji-kelor-moringa-oleiferasebaga

Widiyanti NL \& Ristiati NP (2004). Analisis Kualitatif Bakter Koliform Pada Depo Air Minum Isi I Ulang Di Kota Singaraja Bali. Jurnal ecology Kesehatan. http://ejournal.litbang.kemkes.go.id/index.php /jek/article/view/1332/0 